\title{
PENGARUH KOMPETENSI DAN MOTIVASI TERHADAP KINERJA GURU SMK DI KABUPATEN TANGERANG, BANTEN
}

\author{
Anyes Sedayu Pramesti ${ }^{1,2}$ dan Lisman Manurung ${ }^{2}$ \\ ${ }^{1}$ Direktorat Pembinaan Guru Pendidikan Menengah dan Pendidikan Khusus \\ ${ }^{2}$ Ilmu Administrasi, Universitas Indonesia \\ Email: anyes.pramesti@gmail.com
}

\begin{abstract}
Abstrak
Pengaruh kompetensi dan motivasi terhadap kinerja guru di Indonesia telah banyak diteliti, namun yang secara khusus meneliti guru Sekolah Menengah Kejuruan (SMK) di propinsi yang menyandang Indeks Pembangunan Manusia (IPM) di bawah rata-rata masih terbatas. Penelitian ini adalah tentang pengaruh kompetensi dan motivasi terhadap kinerja guru Sekolah Menengah Kejuruan (SMK) di Kabupaten Tangerang, Provinsi Banten. Penelitian dilaksanakan dengan metode kuantitatif dengan melibatkan sampel sebanyak 112 guru yang mewakili guru-guru PNS bersertifikat di SMK di Kabupaten Tangerang, Banten. Data dianalisis menggunakan analisis regresi linier berganda. Hasil penelitian menunjukkan bahwa (1) ada hubungan positif dan signifikan antara kompetensi dan kinerja guru; (2) ada hubungan positif antara motivasi dan kinerja guru; serta (3) kompetensi dan motivasi secara simultan berpengaruh terhadap kinerja guru dalam konteks guru kejuruan di Kabupaten Tangerang. Penelitian ini merekomendasikan perlunya pemerintah mendorong guru agar menggunakan insentif sertifikasi untuk meningkatkan kompetensi mereka.
\end{abstract}

Kata kunci: kompetensi, motivasi, kinerja guru, sekolah menengah kejuruan, Kabupaten Tangerang.

\section{PENDAHULUAN}

Peranan guru yang berkualitas akan mampu memfasilitasi keberhasilan proses transfer pengetahuan dan kemampuan bagi peserta didiknya (Chetty, Friedman, \& Rockoff, 2011). Pemerintah Indonesia telah melakukan langkah besar dalam rangka mendorong terselenggaranya pendidikan nasional yang baik yakni dengan digulirkannya Undang-Undang Republik Indonesia Nomor 20 Tahun 2003 tentang Sistem Pendidikan Nasional. Undang-undang ini menyatakan bahwa sistem pendidikan nasional harus mampu menjamin kesempatan pendidikan dan peningkatan mutu serta relevansi dan efisiensi manajemen pendidikan untuk menghadapi tantangan sesuai dengan tuntutan perubahan kehidupan lokal, nasional dan global. Pada undang-undang yang sama, pemerintah menetapkan alokasi anggaran pendidikan sebanyak 20\% dari Anggaran Pendapatan dan Belanja Negara (APBN).

Kualitas pendidikan dipengaruhi oleh kualitas pengajaran, dimana guru sangat berperan penting dalam hal kualitas pengajaran. Guru berhadapan langsung dengan para siswa dalam proses pembelajaran di kelas (Ahmadi, dkk, 2011). Prestasi belajar siswa tergantung pada kesiapan guru dalam aktivitas pembelajaran yang didukung oleh pengetahuan, keterampilan, dan praktik guru tersebut. Sosok guru yang kompeten dan profesional mempengaruhi pembelajaran dan prestasi siswa (Barber \& Mourshed, 2007; Rivkin, Hanushek \& Kain, 2000). Sedangkan motivasi ikut berperan membentuk kinerja guru. Motivasi kerja yang tinggi akan menunjang kinerja yang tinggi dan sebaliknya motivasi yang rendah akan berdampak kinerja yang buruk (Rasheed, dkk, 2014; Fathurrohman \& Suryana, 2012). McClelland (1985) mengatakan bahwa motivasi untuk berprestasi merupakan suatu keinginan untuk melakukan yang terbaik, menjadi sukses dan 
merasa mampu/berkompetensi. Motivasi berprestasi bukan untuk mendapat pujian namun untuk kepuasan batin dalam dirinya (McClelland, 1985).

Untuk meningkatkan kinerja guru, pemerintah membuat kebijakan sertifikasi guru yang diamanatkan dalam Undang-Undang Nomor 14 Tahun 2005 tentang Guru dan Dosen. UndangUndang ini mensyaratkan guru untuk memiliki sertifikat pendidik untuk menjadi guru. Perolehan sertifikat oleh para pendidik diharapkan dapat meningkatkan kompetensi dan motivasi guru dalam mengajar. Guru yang memperoleh sertifikat berhak mendapat tunjangan sertifikasi. Biaya untuk mendukung kebijakan program sertifikasi guru dari tahun 2006 - 2015 mencapai Rp 250 triliun (Data dari Kementerian Pendidikan dan Kebudayaan).

Meskipun berbagai upaya telah dilakukan, Indonesia masih berperingkat rendah dalam hal kualitas pendidikan. Laporan UNESCO dalam Education for All Global Monitoring Report, menunjukkan peringkat Indonesia tergolong rendah yakni ke 64 dari 120 negara. Adapun ratarata kemampuan siswa di bidang matematika, science dan kemampuan literasi masih rendah yaitu di peringkat 62 dari 70 negara (PISA, 2015).

Lebih jauh, menurut indikator kemajuan program-program peningkatan kompetensi, program peningkatan kompetensi guru belum memuaskan. Pada Uji Kompetensi Guru (UKG) yang dilakukan secara nasional, hasil UKG menunjukkan taraf rata-rata kompetensi guru untuk seluruh provinsi adalah 56,69 dari skala optimal 100. Adapun rata-rata nilai UKG tertinggi adalah Propinsi DI Yogyakarta $(67,02)$ dan terendah adalah Propinsi Maluku Utara $(44,79)$. Sementara untuk seluruh Pulau Jawa, Propinsi Banten menduduki peringkat paling rendah yakni 55,90.

\section{Hasil Uji Kompetensi Guru 2015}

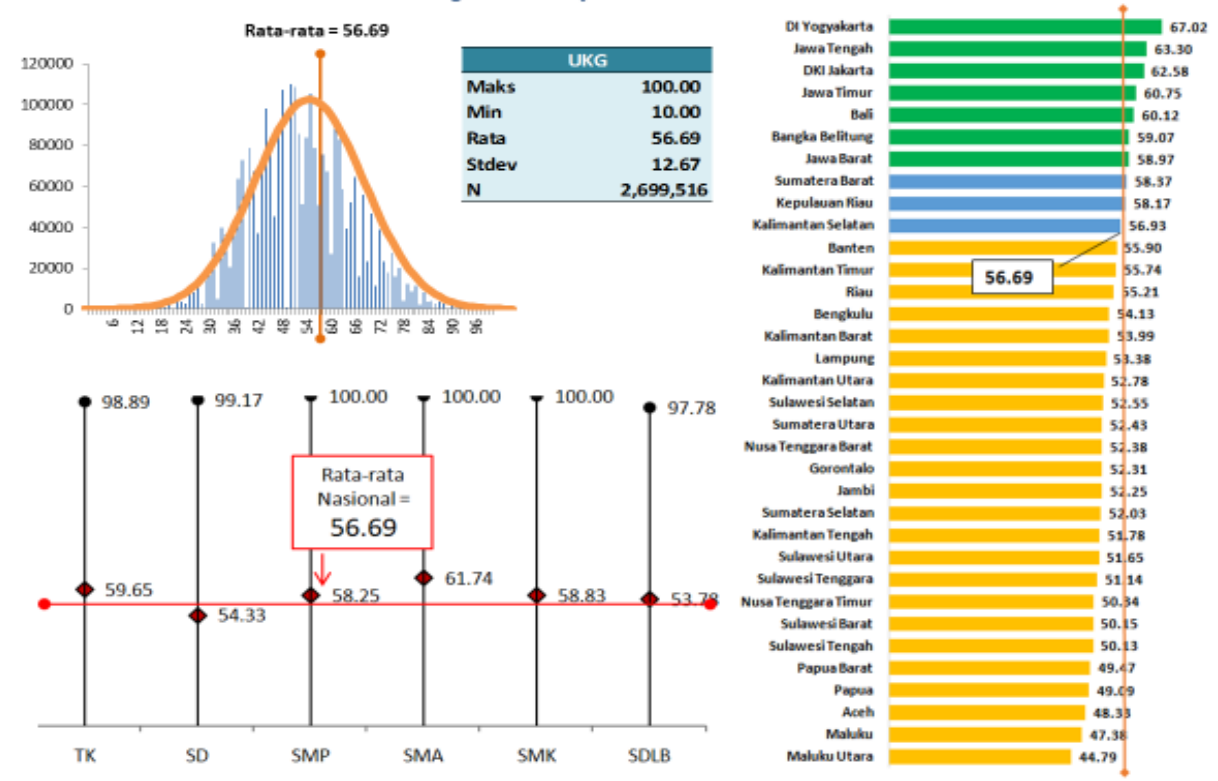

Grafik 1. Hasil Uji Kompetensi Guru 2015

Sumber: Direktorat Pembinaan Guru Pendidikan Menengah dan Khusus

Di samping menyandang predikat UKG terendah di Pulau Jawa, Provinsi Banten juga menyandang Indeks Pembangunan Manusia (IPM) terendah di Pulau Jawa, yaitu sebesar 71,9 (BPS). Di sisi lain, Anggaran Pendidikan Provinsi Banten cukup besar yakni pada tahun 2016 sebesar Rp 1.331,3 milyar (Neraca Pendidikan Banten). Namun demikian, hasil nilai siswa pada Ujian Nasional di Provinsi Banten masih di bawah rata-rata nilai nasional. Hasil rata-rata Ujian Nasional tergambar dalam Grafik 2. 


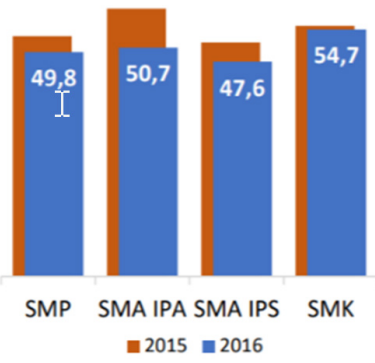

Grafik 2. Hasil UN Provinsi Banten

Sumber: Puspendik 2015

Kebijakan pemerintah dalam mewujudkan guru yang berkualitas telah menghabiskan anggaran yang besar dengan harapan guru dapat berkinerja dengan baik. Namun demikian, hasil rata-rata nilai nasional Uji Kompetensi Guru(UKG) guru SMK Negeri di Kabupaten Tangerang, Banten dan hasil nilai Ujian Nasional siswa SMK masih di bawah nilai rata-rata nasional. Secara keseluruhan Guru SMK di Kabupaten Tangerang terbanyak, yakni 2.568 guru, sebanyak 2.115 guru mengajar di SMK Swasta dan 453 guru di SMK Negeri. Dari jumlah tersebut, guru bersertifikat sebanyak 21\%. Rata-rata nilai Uji Kompetensi Guru berdasarkan status pegawai guru 'non PNS' masih rendah, yakni 54,1 dibandingkan rata-rata nilai Uji Kompetensi Guru PNS yaitu 60,13. Nilai total rata-rata UKG Kabupaten Tangerang sebesar 55,36, masih di bawah rata-rata nilai UKG nasional sebesar 56,69. Pertanyaan penelitian dalam studi ini adalah sebagai berikut:

1. Bagaimana pengaruh kompetensi terhadap kinerja guru di SMK Kabupaten Tangerang?

2. Bagaimana pengaruh motivasi berprestasi terhadap kinerja guru di SMK Kabupaten Tangerang?

3. Bagaimana pengaruh kompetensi dan motivasi berprestasi terhadap kinerja guru di SMK Kabupaten Tangerang?

Tujuan penelitian ini adalah untuk memperoleh data informasi tentang pengaruh kompetensi dan motivasi berprestasi terhadap kinerja guru di SMK Negeri Kabupaten Tangerang.

Adapun secara khusus tujuan penelitian ini adalah menguji adanya pengaruh kompetensi terhadap kinerja guru di SMK Negeri Kabupaten Tangerang, menguji adanya pengaruh motivasi berprestasi terhadap kinerja guru di SMK Negeri Kabupaten Tangerang, dan menguji adanya pengaruh dari kompetensi dan motivasi berprestasi terhadap kinerja guru di SMK Negeri Kabupaten Tangerang. Lebih jauh, dalam rangka pengembangan Sumber Daya Manusia terampil dan siap kerja, pemerintah telah menerbitkan Instruksi Presiden (Inpres) Nomor 9 Tahun 2016 mengenai Revitalisasi Sekolah Menengah Kejuruan (SMK). Program revitalisasi SMK merupakan salah satu program unggulan Pemerintahan Jokowi-JK.

\section{METODE PENELITIAN}

Metode penelitian yang digunakan dalam penelitian ini adalah metode kuantitatif. Instrumen pengumpulan data adalah kuesioner yang disusun menurut daftar kebutuhan data. Populasi penelitian ini adalah guru SMK yang berstatus PNS dan telah memperoleh sertifikasi. Jumlah seluruh guru Sekolah Menengah Kejuruan di Kabupaten Tangerang adalah 2.568 guru sedangkan yang berstatus PNS dan telah memperoleh sertifikasi adalah 21\%. Jumlah seluruh sampel yang memenuhi syarat adalah 112. Pengolahan data menggunakan program SPSS. Pengujian hipotesis menggunakan analisis regresi berganda.

Seluruh responden penelitian ini berjumlah 112 orang guru PNS SMK yang bersertifikat. Adapun jumlah seluruh guru yang mengajar di SMK Kabupaten Tangerang 2.568 guru. Guru SMK 
Negeri sebanyak 17,64\%, selainnya mengajar di SMK Swasta. Adapun jumlah guru SMK PNS yang bersertifikat di Kabupaten Tangerang adalah 540 guru atau 21\%. Sampel penelitian ini sebanyak 55,4\% adalah responden perempuan. Dari segi usia, dengan rentang kelompok 5 tahun, kelompok sampel terbanyak adalah pada usia 50 tahun sampai dengan 55 tahun yaitu 37 orang atau $33,0 \%$. Sedangkan kelompok guru muda yaitu antara 30 sampai dengan 35 tahun hanya 5 orang atau 4,5\%. Adapun struktur responden menurut jabatan ditunjukkan oleh 3 jenjang, yakni Guru Pratama, Guru Muda dan Guru Madya. Kelompok terbesar adalah kelompok Guru Muda yakni $68,8 \%$. Status kepegawaian responden adalah PNS, mulai dari Golongan III/a sampai dengan IV/b. Sedangkan menurut kategori, yang terbanyak adalah Golongan III/d yaitu sebanyak 48 orang atau $42,9 \%$.

\section{HASIL PENELITIAN \& PEMBAHASAN}

Penelitian ini mengenai kompetensi guru. Rata-rata nilai Uji Kompetensi Guru (UKG) PNS di Kabupaten Tangerang adalah 60,13. Sedangkan UKG pegawai berstatus non PNS relatif rendah yaitu 54,1. Rata-rata nilai UKG termasuk pegawai non PNS adalah 55,36. Rata-rata nilai UKG nasional sebesar 56,69. Adapun kualifikasi guru SMK di Kabupaten Tangerang yaitu yang telah mencapai pendidikan Sarjana S1 adalah 666 guru. Rata-rata UKG Sarjana S1 adalah sebesar 55,52 sedangkan guru yang belum S1 sebanyak 17 orang dengan rata-rata UKG sebesar 49,17.

\section{Hasil Analisis Instrumen}

Uji instrumen dilakukan dengan menggunakan program SPSS versi 23. Uji ini dimaksudkan untuk mendeteksi kelayakan alat pengumpul data berupa angket. Hasil pengujian instrumen menunjukkan bahwa instrumen yang digunakan pada penelitian ini valid dan reliabel.

\section{Hasil Uji Asumsi Klasik}

Hasil uji asumsi klasik menunjukkan bahwa data berasal dari distribusi normal, tidak terdapatnya multikolinieritas dan tidak adanya heterokedastisitas, maka data dapat diolah dengan menggunakan teknik analisis regresi linier berganda.

\section{Hasil Uji Hipotesis}

Uji regresi berganda digunakan untuk mengetahui seberapa besarnya kontribusi dari masingmasing variabel independen (Kompetensi Guru dan Motivasi Guru) terhadap variabel dependen Kinerja Guru. Berikut hasil analisis regresi dengan menggunakan bantuan program SPSS.

Tabel 1. Hasil Analisis Regresi Menggunakan Program SPSS

\section{Coefficients $^{\mathrm{a}}$}

\begin{tabular}{|ll|r|r|r|r|r|}
\hline & & \multicolumn{2}{|c|}{$\begin{array}{c}\text { Unstandardized } \\
\text { Coefficients }\end{array}$} & \multicolumn{2}{c|}{$\begin{array}{c}\text { Standardized } \\
\text { Coefficients }\end{array}$} & \\
\cline { 3 - 7 } Model & & \multicolumn{1}{|c|}{ B } & Std. Error & \multicolumn{1}{c|}{ Beta } & \multicolumn{1}{c|}{$\mathrm{t}$} & \multicolumn{1}{c|}{ Sig. } \\
\hline 1 & (Constant) & 2.076 & 1.469 & & 1.413 & .160 \\
& X1_Kompetensi & .556 & .076 & .530 & 7.324 & .000 \\
& X2_Motivasi & .533 & .087 & .443 & 6.125 & .000 \\
\hline
\end{tabular}

Berdasarkan hasil olah data dalam tabel di atas, dapat disusun persamaan regresi berikut:

$$
\begin{aligned}
& \mathrm{Y}=\mathrm{a}+\mathrm{b}_{1} \mathrm{X}_{1}+\mathrm{b}_{2} \mathrm{X}_{2}+\mathrm{e} \\
& \mathrm{Y}=2,076+0,556 \mathrm{X}_{1}+0,553 \mathrm{X}_{2}+\varepsilon
\end{aligned}
$$


Keterangan:

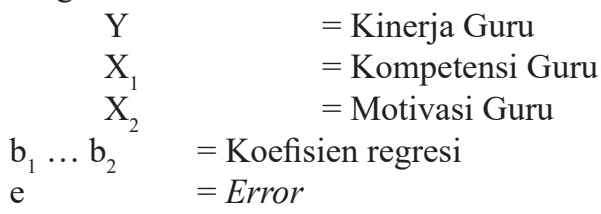

Persamaan regresi di atas dapat dijelaskan sebagai berikut. Konstanta sebesar 2,076 artinya jika Kompetensi Guru $\left(\mathrm{X}_{1}\right)$ dan Motivasi Guru $\left(\mathrm{X}_{2}\right)$ nilainya adalah 0, maka nilai kinerja guru $(\mathrm{Y})$ adalah sebesar 2,067. Koefisien regresi variabel Kompetensi Guru $\left(\mathrm{X}_{1}\right)$ sebesar 0,556, artinya jika variabel independen lainnya tetap dan nilai Kompetensi Guru $\left(\mathrm{X}_{1}\right)$ mengalami kenaikan 1 $\%$, maka besaran nilai Kinerja Guru akan mengalami kenaikan sebesar 0,556. Koefisien bernilai positif artinya terjadi hubungan positif antara Kompetensi Guru dengan Kinerja, semakin naik nilai kompetensi guru maka semakin besar nilai Kinerja Guru.

Koefisien regresi variabel Motivasi Guru $\left(\mathrm{X}_{2}\right)$ sebesar 0,553 , artinya jika variabel independen lainnya tetap dan nilai Motivasi Guru $\left(\mathrm{X}_{2}\right)$ mengalami kenaikan $1 \%$, maka besaran nilai Kinerja Guru akan mengalami kenaikan sebesar 0,553. Koefisien bernilai positif artinya terjadi hubungan positif antara Motivasi Guru dengan Kinerja, semakin naik nilai Motivasi guru maka semakin besar nilai Kinerja Guru.

\section{Analisis Determinasi $\left(\mathbf{R}^{2}\right)$}

Analisis Determinan $\left(\mathrm{R}^{2}\right)$ dipergunakan untuk mengetahui proporsi variabel independen. Analisis determinasi dalam regresi linier berganda digunakan untuk mengetahui prosentase sumbangan pengaruh variabel independen $\left(\mathrm{X}_{1}, \mathrm{X}_{2}, \ldots . \mathrm{X}_{\mathrm{n}}\right)$ secara serentak terhadap variabel dependen $(\mathrm{Y})$. Apabila $\mathrm{R}^{2}$ sama dengan 1, maka prosentase sumbangan besar.

Dari hasil analisis regresi, dilihat pada output model summary dan disajikan sebagai berikut:

Tabel 2. Hasil Analisis Determinasi

Model Summary

\begin{tabular}{|l|l|r|r|r|}
\hline Model & R & R Square & $\begin{array}{c}\text { Adjusted R } \\
\text { Square }\end{array}$ & $\begin{array}{c}\text { Std. Error of } \\
\text { the Estimate }\end{array}$ \\
\hline 1 &, $951^{\text {a }}$ &, 905 &, 903 & 3,73710 \\
\hline
\end{tabular}

a. Predictors: (Constant), X2_Motivasi, X1_Kompetensi

b. Dependent Variable: Y_Kinerja

Koefisien determinasi $\left(\mathrm{R}^{2}\right)$ pada intinya mengukur seberapa jauh kemampuan model dalam menerangkan variasi variabel terikat. Hasil analisis menunjukkan nilai $\mathrm{R}^{2}$ adalah 0,905 berarti sebesar 90,5\% variabel yang dipilih pada variabel independen dapat menerangkan variasi variabel dependen, sedangkan sisanya 9,5\% diterangkan oleh variabel lainnya. Dengan demikian penggunaan variabel independen dalam menerangkan variasi variabel dependen sudah memenuhi syarat.

\section{Uji t}

Uji ini dilakukan untuk mengetahui pengaruh signifikan secara parsial antara variabel independen terhadap variabel dependen sebagai berikut. 


\section{Coefficients $^{\mathrm{a}}$}

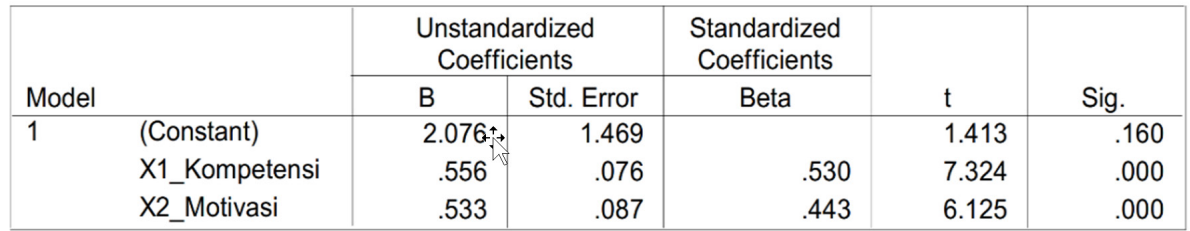

\section{Pengujian Koefisien Regresi Variabel Kompetensi Guru}

\section{Rumusan Hipotesis}

Ho : Secara parsial tidak ada pengaruh signifikan antara Kompetensi Guru dengan Kinerja Guru

Ha : Secara parsial ada pengaruh signifikan antara Kompetensi Guru dengan Kinerja Guru

Bilamana nilai $\mathrm{t}_{\text {hitung }}>\mathrm{t}_{\text {tabel}}$, maka hipotesis nol (Ho) ditolak sehingga hipotesis Alternatif (Ha) diterima, sebaliknya jika nilai $\mathrm{t}_{\text {hitung }}<\mathrm{t}_{\text {tabel }}$ maka hipotesis nol (Ho) diterima dan hipotesis alternatif (Ha) ditolak.

Bahwa variabel Kompetensi Guru diperoleh $t_{\text {hitung }}$ sebesar $=7,324$ dan $t_{\text {tabel }}$ pada $n 112$ dan $\alpha 1 \%$ adalah 2,576; $\mathrm{t}_{\text {tabel }}$ pada $\mathrm{n} 112$ dan $\alpha 5 \%$ adalah 1,960, sehingga $\mathrm{t}_{\text {hitung }}>\mathrm{t}_{\text {tabel }}$ maka Ho ditolak, berarti ada pengaruh yang signifikan antara variabel Kompetensi Guru terhadap Kinerja Guru hal ini diperkuat nilai Sig $0,000<0,05$.

\section{Pengujian Koefisien Regresi Variabel Motivasi Guru}

Rumusan Hipotesis

Ho : Secara parsial tidak ada pengaruh signifikan antara Kompetensi Guru dengan Kinerja Guru

Ha : Secara parsial ada pengaruh signifikan antara Kompetensi Guru dengan Kinerja Guru

Bilamana nilai $t_{\text {hitung }}>\mathrm{t}_{\text {tabel}}$, maka hipotesis nol (Ho) ditolak dan hipotesis alternatif diterima sebaliknya jika nilai $\mathrm{t}_{\text {hitung }}<\mathrm{t}_{\text {tabel }}$ maka hipotesis nol (Ho) diterima dan hipotesis alternatif (Ha) ditolak. Bahwa variabel Motivasi Guru diperoleh $t_{\text {hitung }}$ sebesar $=6,125$ dan $t_{\text {tabel }}=1,960$ maka $t_{\text {hitung }}$ $>t_{\text {tabel, }}$, sehingga Ho ditolak, berarti ada pengaruh yang signifikan antara variabel Motivasi Guru terhadap kualitas pembelajaran hal ini diperkuat nilai signifikansi $0,000<0,05$.

\section{Uji F}

Uji ini dilakukan untuk mengetahui pengaruh signifikan secara simultan antara variabel independen terhadap variabel dependen. Untuk mengetahui nilai $\mathrm{F}$ test dapat diketahui dari nilai sig pada tabel Anova dalam output regression SPSS versi 23 for windows.

ANOVA $^{\text {b }}$

\begin{tabular}{|ll|r|r|r|r|r|}
\hline Model & & \multicolumn{1}{|c|}{ Sum of } & & & \\
\hline 1 & Squares & df & Mean Square & \multicolumn{1}{c|}{$\mathrm{F}$} & \multicolumn{1}{c|}{ Sig. } \\
\hline & Regression & 14492.709 & 2 & 7246.355 & 518.861 & $.000^{\mathrm{a}}$ \\
& Residual & 1522.282 & 109 & 13.966 & & \\
\hline & Total & 16014.991 & 111 & & & \\
\hline
\end{tabular}

a. Predictors: (Constant), X2_Motivasi, X1_Kompetensi

b. Dependent Variable: Y_Kinerja

Uji statistik F pada dasarnya menunjukkan apakah semua variabel bebas yang dimasukkan dalam model mempunyai pengaruh secara bersama-sama terhadap variabel terikat. 


\section{Berikut Rumusan Hipotesis}

Ho : Tidak ada pengaruh secara signifikan antara Kompetensi Guru dan Motivasi Guru secara bersama-sama terhadap Kinerja Guru.

Ha : Ada pengaruh secara signifikan antara Kompetensi Guru dan Motivasi Guru secara bersama-sama terhadap Kinerja Guru.

Kriteria pengujian:

Ho diterima apabila $\mathrm{F}$ hitung $<\mathrm{F}$ tabel.

Ho ditolak apabila $\mathrm{F}$ hitung $>\mathrm{F}$ tabel.

Berdasarkan hasil uji $\mathrm{F}$ diperoleh nilai $\mathrm{F}_{\text {hitung }}=518,68$; dan $\mathrm{F}_{(0.05 ; 112)}=3,09$, karena $\mathrm{F}_{\text {hitung }}>\mathrm{F}_{\text {tabel }}$, maka Ho ditolak maka ada pengaruh yang signifikan antara Kompetensi Guru dan Motivasi Guru secara bersama-sama terhadap Kinerja Guru.

\section{Pembahasan}

Tujuan penelitian ini adalah untuk menguji adanya pengaruh kompetensi dan motivasi kerja pada kinerja guru. Hasil uji hipotesis menunjukkan bahwa (1) kompetensi berpengaruh positif dan signikan terhadap kinerja guru, (2) motivasi berpengaruh positif dan signifikan terhadap kinerja guru; dan (3) motivasi dan kompetensi berpengaruh secara simultan terhadap kinerja guru. Studi ini membahas kaitan dengan kebijakan pemerintah tentang sertifikasi dan tunjangan profesi guru dengan menganalisis hubungan-hubungan antara variabel yang meliputi variabel Kompetensi, Motivasi dan Kinerja.

\section{Kompetensi}

Pengukuran kompetensi dalam penelitian ini mengikuti pola pengukuran yang dilakukan oleh sekolah. Berdasarkan hasil pengolahan atas data yang diliput dengan instrumen pengumpulan data kuantitatif maka responden menilai tentang kompetensi mereka sendiri berada pada nilai minimal 1,26 dan maksimal 3,47 dan skor rata-rata 2,28. Selanjutnya data kompetensi guru tersebut dapat dikategorikan dengan menggunakan skor rata-rata (mean) dan simpangan baku (standard deviation). Kategori Tinggi $>2,85$; Kategori Sedang 1,71 $<\mathrm{n}<2,85$; Kategori Rendah $<1,71$. Distribusi frekuensi berdasarkan kategori ini untuk variabel kompetensi adalah seperti pada Grafik 3.

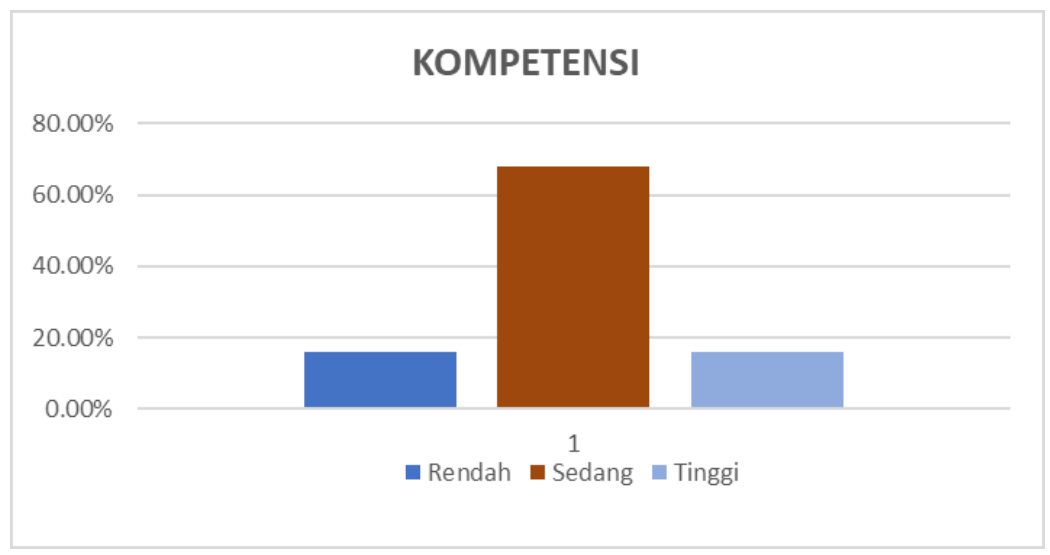

Grafik 3. Distribusi Frekuensi Kompetensi Guru

Dari grafik di atas dapat disimpulkan bahwa responden memiliki tingkat kinerja dalam kategori sedang dengan jumlah 75 orang responden (66,9\%). Sedangkan untuk kategori tinggi terdapat banyak 18 orang responden $(16,1 \%)$ dan kategori rendah sebanyak 19 orang responden $(17,1 \%)$. 
Artinya dapat disimpulkan bahwa kinerja guru SMK Kabupaten Tangerang berada dalam kategori sedang, sehingga perlu upaya peningkatan kinerja guru.

Hasil uji kompetensi guru SMK di Kabupaten Tangerang, dapat dilihat dalam grafik berikut.

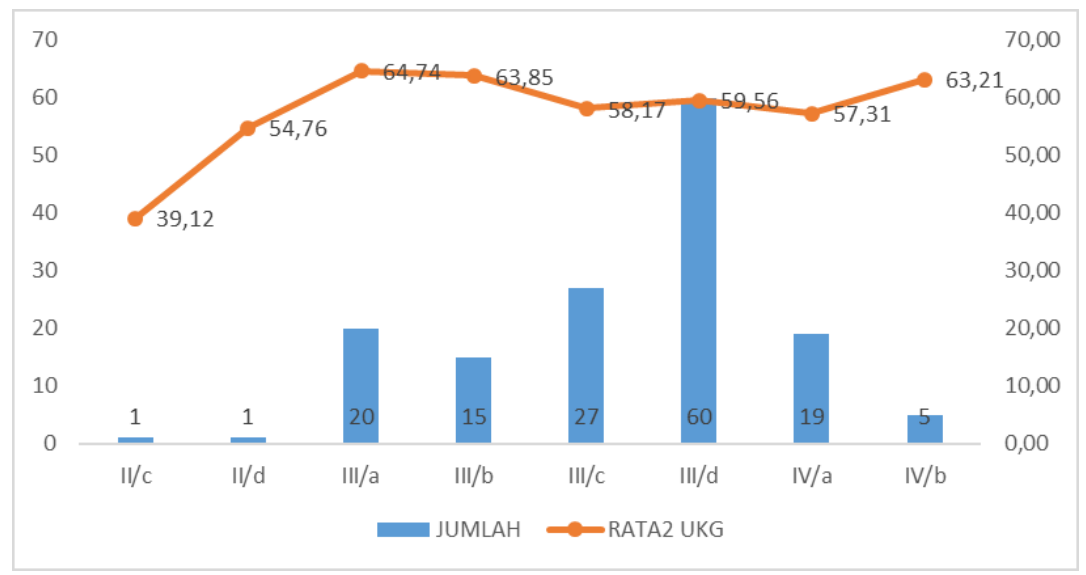

Grafik 4. Responden menurut Golongan Kepangkatan

Berdasarkan data nilai rata-rata Uji Kompetensi Guru (UKG) guru SMK di Kabupaten Tangerang nilai rata-rata tertinggi UKG guru Golongan III/a dan III/b, sehingga (variabel) tingkat golongan guru kurang cocok digunakan sebagai prediktor hasil nilai kompetensi guru. Nilai rata-rata Uji UKG Guru SMK berstatus PNS dan telah memiliki sertifikat masih rendah. Perlu diketahui bahwa Provinsi Banten merupakan provinsi baru hasil pemekaran dari Provinsi Jawa Barat. Pemekaran ini diatur dengan Undang-Undang Nomor 23 Tahun 2000.

\section{Motivasi}

Berdasarkan hasil pengolahan dari kuesioner, guru-guru SMK di Kabupaten Tangerang memiliki skor motivasi minimal 1,00, maksimal 3,67, skor rata-rata 2,40 dan standard deviasi 0,62. Data motivasi guru tersebut dikategorikan dengan menggunakan skor rata-rata (mean) dan simpangan baku (standard deviation), dengan kategori Tinggi $>3,01$; Sedang 1,78 $<\mathrm{n}<3,01$; dan Kategori Rendah $<1,78$. Distribusi frekuensi kategori untuk variabel motivasi terdapat pada Grafik 5.

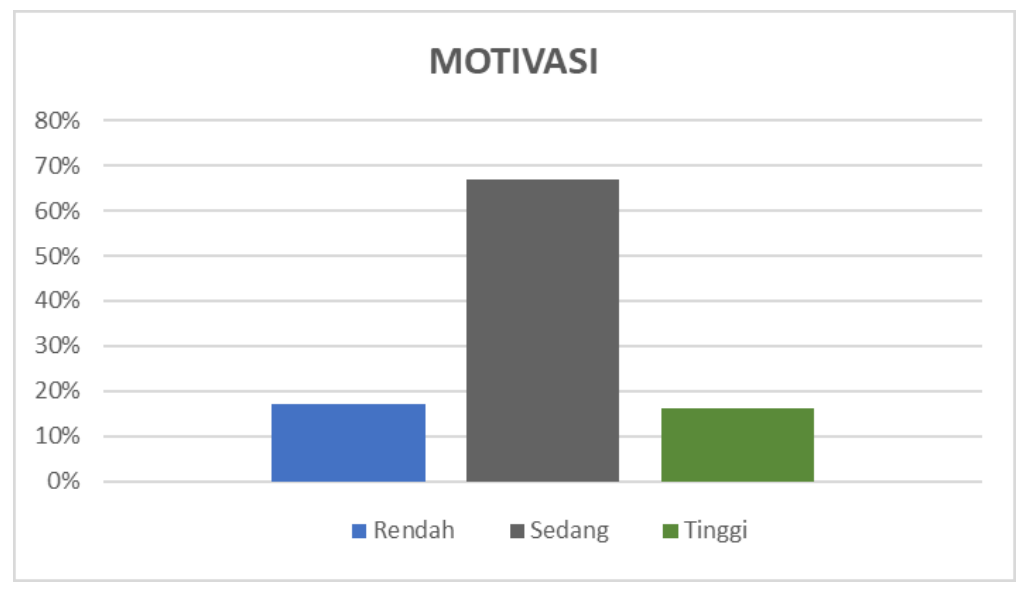

Grafik 5. Distribusi Frekuensi Motivasi

Dari Grafik 5 dapat disimpulkan bahwa responden memiliki tingkat motivasi dalam kategori sedang dengan jumlah 75 orang responden (67\%), kategori tinggi sebanyak 25 orang responden 
(16\%) dan kategori rendah sebanyak 19 orang responden (17\%). Dapat disimpulkan bahwa tingkat motivasi guru SMK Kabupaten Tangerang berada dalam kategori sedang.

Untuk mengkaji indikator-indikator yang perlu ditingkatkan pada variabel motivasi, peneliti mengkaji lebih lanjut item-item kuesioner yang memiliki nilai rendah pada variabel motivasi. Hasil kajian menunjukkan indikator kebutuhan dalam mencapai kesuksesan memiliki nilai rendah. Hasil penelitian menunjukkan bahwa guru SMK di Kabupaten Tangerang kurang termotivasi dalam hal pengembangan karir seperti naik pangkat dan golongan. Winarno dan Perdana (2015) menyatakan bahwa motivasi berpengaruh signifikan dan positif pada kinerja, sehingga untuk meningkatkan kinerja guru perlu adanya peningkatan motivasi guru. Dengan menginterpretasikan data tersebut dapat dikatakan bahwa guru SMK di Kabupaten Tangerang kurang termotivasi untuk berkinerja tinggi, karena kinerja dikaitkan dengan kenaikan pangkat dan golongan, yakni pemenuhan angka kredit, namun menurut mereka standar kenaikan pangkat ini pada dasarnya sulit terpenuhi bagi mereka. Untuk memenuhi angka kredit tersebut guru wajib melaksanakan kegiatan Pengembangan Keprofesian Berkelanjutan (PKB), yaitu pengembangan diri, publikasi ilmiah, dan/atau pengembangan karya inovatif. Publikasi ilmiah yang dimaksud dalam Peraturan Menteri Nomor 35 Tahun 2010 yaitu publikasi ilmiah hasil penelitian atau gagasan inovatif pada bidang pendidikan formal, publikasi buku teks pelajaran, buku pengayaan dan pedoman guru.

Selain mengajar, guru harus dapat aktif dalam kegiatan organisasi guru seperti MGMP dan sebagainya. Keaktifan guru SMK di Kabupaten Tangerang dalam mengikuti organisasi guru juga masih rendah. Berdasarkan Undang-Undang Nomor 14 Tahun 2005 pasal 41 ayat 3 tentang Guru dan Dosen menyebutkan bahwa guru wajib menjadi anggota organisasi. Dengan mengikuti dan aktif berorganisasi guru diharapkan dapat berbagi baik ilmu dunia pendidikan maupun pengalaman proses mengajar, selain itu guru dapat mengelola kelas dengan baik, berjiwa sosial, kematangan berpikir, menunjang karir dan meningkatkan profesionalismenya.

Atas analisis data yang diolah dari hasil kuesioner, item terkait pemaksimalan sumber daya memperoleh rating nilai yang rendah. Pemerintah perlu menstimulasi guru agar lebih peduli meraih kenaikan pangkat. Guru belum memperoleh sarana untuk menampung aktifitas berorganisasi. Sebagai contoh, wadah musyawarah guru untuk meningkatkan kualitas mata pelajaran (MGMP) hendaknya ditumbuh-kembangkan.

\section{Kinerja}

Hasil analisis deskriptif pada variabel kinerja menunjukkan nilai minimum sebesar 1,26 dan maksimum sebesar 3,47 dengan nilai rata-rata sebesar 2,39 dan standar deviasi sebesar 0,60. Selanjutnya data kinerja guru dikategorikan dengan menggunakan skor rata-rata (mean) dan simpangan baku (standard deviation). Kategorisasi untuk variabel kinerja terdapat pada grafik berikut:

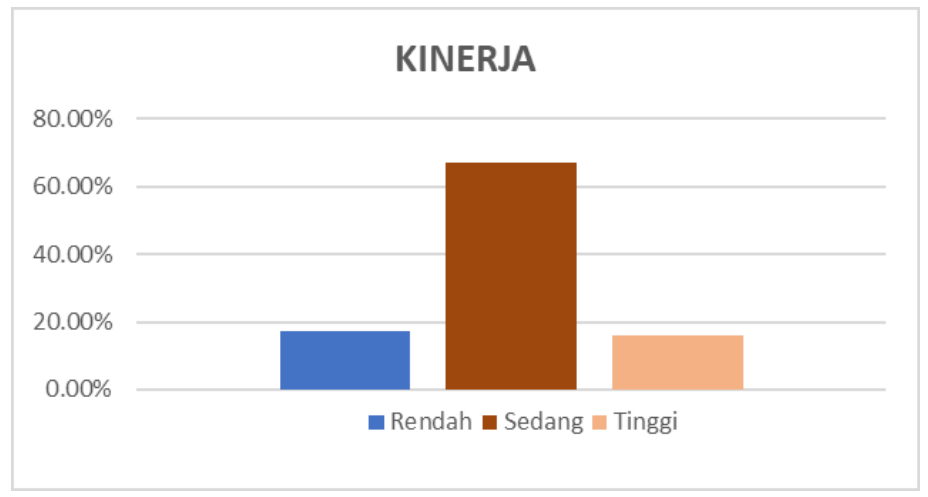

Grafik 6. Kategori Kinerja 
Dari grafik di atas dapat disimpulkan bahwa responden memiliki tingkat kinerja dalam kategori sedang dengan jumlah 75 orang responden (66,9\%). Sedangkan untuk kategori tinggi terdapat sebanyak 18 orang responden $(16,1 \%)$ dan kategori rendah sebanyak 19 orang responden (17,1\%). Dapat disimpulkan bahwa kinerja guru SMK Kabupaten Tangerang berada dalam kategori sedang, sehingga perlu upaya peningkatan kinerja guru.

\section{Pengaruh Kompetensi terhadap Kinerja Guru SMK di Kabupaten Tangerang}

Kompetensi terkait erat dengan kinerja. Angka Kredit penilaian kinerja guru merupakan penilaian dari tugas utama guru dalam rangka pembinaan karier kepangkatan dan jabatannya. Pengembangan kompetensi guru dapat dilakukan dengan cara seperti mengikuti penataran guru, mengikuti MGMP, kursus, menambah pengetahuan melalui media massa atau elektronik dan belajar sendiri.

\section{Pengaruh Motivasi terhadap Kinerja Guru SMK di Kabupaten Tangerang}

Selain variabel kompetensi, penelitian ini menguji hipotesis adanya hubungan antara motivasi dengan kinerja guru. Hasil penelitian menunjukkan adanya pengaruh motivasi terhadap kinerja guru dilihat dari nilai signifikansi dan $\mathrm{t}_{\text {hitung }}$ sebesar 0,000 dan 6,125 .

Mengingat motivasi berpengaruh terhadap kinerja guru, pemerintah hendaknya mengupayakan agar faktor-faktor yang menghambat motivasi guru agar segera ditangani.

\section{Pengaruh Kompetensi dan Motivasi Guru terhadap Kinerja Guru SMK di Kabupaten Tangerang}

Tujuan penelitian ini menguji adanya pengaruh kompetensi dan motivasi guru secara simultan pada kinerja guru. Hasil analisis data menunjukkan bahwa kompetensi dan motivasi guru berpengaruh positif dan signifikan terhadap kinerja guru SMK di Kabupaten Tangerang. Hasil penelitian tersebut sejalan dengan hasil-hasil penelitian sebelumnya. Hasil penelitian Nugraha, dkk. (2017) menyimpulkan bahwa motivasi dan kompetensi guru secara positif dan signifikan berpengaruh bersamaan terhadap kinerja guru. Winarno dan Perdana (2015) juga mengungkapkan bahwa kompetensi dan motivasi berpengaruh signifikan dan positif pada kinerja secara bersamaan sebesar 54,70\%. Wijaya (2015) dan Rohimah (2013) yang menyatakan secara simultan kompetensi dan motivasi berpengaruh terhadap kinerja guru.

Pemberian tunjangan guru sepertinya belum berdampak besar terhadap kinerja guru. Guru SMK Negeri di Kabupaten Tangerang belum memanfaatkan tunjangan guru untuk meningkatkan kompetensi mereka.

\section{KESIMPULAN}

\section{Simpulan}

Kompetensi dan motivasi berpengaruh signifikan terhadap kinerja guru Sekolah Menengah Kejuruan (SMK) di Kabupaten Tangerang Provinsi Banten.

1. Terdapat hubungan korelasi yang kuat antara variabel kompetensi dengan variabel kinerja guru. Ini berarti kompetensi guru berpengaruh positif dan signifikan terhadap kinerja guru.

2. Terdapat hubungan korelasi yang antara variabel motivasi dengan variabel kinerja guru. Ini berarti motivasi untuk berprestasi guru berpengaruh positif dan signifikan terhadap kinerja guru.

3. Terdapat hubungan korelasi yang kuat antara variabel kompetensi dan variabel motivasi dengan variabel kinerja guru. Ini dapat diartikan bahwa secara bersama-sama dua komponen secara bersama-sama berpengaruh positif dan signifikan terhadap kinerja guru. 
Adapun terkait dengan sertifikasi dan pemberian tunjangan profesi guru, penelitian ini belum memperlihatkan ada atau tidaknya dampaknya pada peningkatan kinerja guru.

\section{Saran}

Peningkatan kompetensi guru dapat dilakukan dengan beberapa cara antara lain program pengembangan guru serta menggalang guru untuk berinovasi guna memperbaharui pengetahuan dalam pembelajaran. Tunjangan profesi hendaknya dapat digunakan oleh para guru untuk membiayai keikutsertaan dalam diklat, seminar dan pelatihan/workshop. Dengan demikian pengembangan kompetensi guru dapat terjadi. Keikutsertaan pada diklat, seminar dan pelatihan/ workshop merupakan kesempatan guru untuk berbagi pengalaman mengajar.

Pemerintah perlu membuat program yang dapat memotivasi guru untuk lebih berprestasi dan mengembangkan diri. Melalui keikutsertaan pada diklat, seminar dan kompetisi publikasi ilmiah, para guru SMK dan para guru pada umumnya dapat mengembangkan diri.

\section{DAFTAR RUJUKAN}

Arifin, H. M. (2015). The Influence of Competence, Motivation, and Organisational Culture to High School Teacher Job Satisfaction and Performance. International Education Studies, Vol. 8, No. 1, pp. 38-45.

Barber, M. \& Mourshed, M. (2007). How the World's Best-performing Schools Systems Come Out On Top. McKinsey \& Company.

Chetty, R., Friedman, J.N, \& Rockoff, J.E. (2011). Teachers: Teacher Value-added and Student Outcomes and Adulthood. Cambridge, MA: National Bureau of Economic Research.

Gynor, C. (1998). Decentralization of Education. Teacher Management. Directions in Development. Washington, D. C.

Hanushek, E.A., \& Rivkin, S. G. (2006). Teacher Quality. Handbook of Economics of Education, vol 2.

Fathorrahman. (2017). Kompetensi Pedagogik, Profesional, Kepribadian dan Kompetensi Sosial Dosen. AKADEMIKA; VOL. 15 No. 1, Februari .

Kolbe, T., \& Strunk, K. O. (2012). Economic Incentives as A Strategy for Responding to Teacher Staffing Problems: A Typology of Policies and Practices. Educational Administration Quarterly, 48, 779-813.

Kolibacova, G. (2014). The relationship between Competency and Performance. Acta Universitatis Agriculturae Et Silviculturae Mendelianae Brunensis. Vol 62. http://dx.doi. org/10.11118/actaun201462061315

Kwapong, L. S. A., Opoku, E., \& Donyina, F. (2015). “The Effect Of Motivation On The Performance Of Teaching Staff In Ghanaian Polytechnics: The Moderating Role Of Education And Research Experience". Global Journal of Human Resource Management, Vol.3, No.6, pp.30-43.

Mardia, H. R. (2014). Professional Competence, Pedagogical Competence and the Performance of Junior High School of Science Teachers. Journal of Education and Practice, ISSN 2222-1735 (Paper) ISSN 2222-288x (Online) Vol. 5, No. 9, http: www. iiste. Org

Matthew, D. M (2015). Teacher Quality and Effectiveness: The Nucleus of Education. The Center of Faculty Excellence, United States Military Academy, West Point, New York.

Mruma, M. J. (2011). Effect Of Motivation Factors On Teachers'Performance In Tanzanian Education Institution; A Case Of Public Secondary Schools In Nyamagana District, Mwanza. A Dissertation Submitted In Partial Fulfillment Of The Requirements For The Master In Human Resources Management Of The Open University Of Tanzania 
Muammar, Darmoko, P.D., Srifariyati \& Muntoha. (2017). Dampak Tunjangan Sertifikasi terhadap Kinerja Guru. Jurnal Madaniyah, Volume 1 Edisi XII Januari .

Rasheed, M.I., Humayon, A.A, Awan, U., \& Ahmed, A. (2014) Factors affecting teacher's motivation an. HRM challenge for public sector higher educational institutions of Pakistan (HEIs). Department of Management Sciences, COMSATs Institute of Information Technology, Vehari, Pakistan. www. Emeraldinsight. com. 2014

Nawawi, H. (2006). Evaluasi dan Manajemen Kinerja di Lingkungan Perusahaan dan Industri. Jogyakarta: Gadjah Mada University Press.

OECD. (2009). Creating Effetive Teaching and Learning Environtments. First Results from TALIS-ISBN 978-92-64-05605-3. 2009

Parmin. (2017). Pengaruh Kompensasi, kompetensi dan motivasi kerja terhadap kinerja guru tidak tetap (GTT) dengan kepuasan kerja sebagai variable intervening. Jurnal Fokus Bisnis. Vol. 16 No 01, Juli

Robbins, S. P. \& Judge, T.A. (2017). Organizational Behavior. $17^{\text {th }}$ Edition. Global Edition. England: Pearson Education Limited.

Siti, R. (2013). Pengaruh kompetensi, kompensasi, disiplin kerja terhadap kinerja dan kepuasan kerja guru SMA Islamic Village Karawaci Tangerang. Thesis MM, Program Pascasarjana Universitas Esa Unggul, Jakarta. 2013

Spencer, L. M. \& Spencer, S. M. (1993). Competence at Work. New York: John Willey \& Sons.

Subroto, W.T. (2013). Income and Implications of teacher performance to improve the quality of education in the elementary school of Surabaya. International Journal of Business, Humanities and Technology Vol. 3 No 2, February 2013

Sudarjat, J., Abdullah, T., \& Sunaryo, W. (2015). Supervision, Leadership, and Working Motivation to Teachers' Performance. International Journal of Managerial Studies and Research (IJMSR), Vol. 3, No. 6, pp. 146-152.

Wahyuni, D. U. Christiananta, B., \& Eliyana, A. (2014). Influence of Organizational Commitment, Transactional Leadership, and Servant Leadership to the Work Motivation, Work Satisfaction and Work Performance of Teachers at Private Senior High Schools in Surabaya, Educational Research International, Vol. 3, No. 2, pp. 82-96.

Wijaya, D. K. (2015). Pentingnya Komunikasi Organisasi, Motivasi Kerja Dan Kompensasi Untuk Meningkatkan Kinerja Guru. Fakultas MIPA Jurusan Kimia IKIP Jakarta (UNJ). Jurnal MIX, Volume VI, No. 2, Juni. 